\title{
Immunopurification and Characterization of A Neuronal Heparan Sulfate Proteoglycan ${ }^{1}$
}

\author{
WILLIAM D. MATTHEW, ${ }^{2}$ RALPH J. GREENSPAN, ${ }^{3}$ ARTHUR D. LANDER, AND LOUIS F. REICHARDT \\ Department of Physiology. Division of Neurobiology. University of California, San Francisco, California 94143
}

\begin{abstract}
We have identified a unique heparan sulfate (HeS) proteoglycan synthesized by the neuronal-like cell line PC12. The proteoglycan, purified with monoclonal antibodies from medium conditioned by PC12 cells, has an apparent molecular weight of 350,000 , and it contains a $M_{r} \mathbf{8 0 , 0 0 0}$ core protein and $\mathrm{HeS}$ side chains of $M_{\mathrm{r}} 15,000$ each. The purified molecule has the same apparent size and density as it has in conditioned medium.
\end{abstract}

HeS proteoglycans that are indistinguishable antigenically but very difficult to solubilize are found on the external surface and in the interior of PC12 cells and neurons. Mild proteolysis converts the surface proteoglycan into a molecule closely resembling that found in the medium. The same surface antigens are also present on a subpopulation of $\mathrm{T}$ cells and on a non-neuronal accessory cell found in dorsal root ganglion cultures.

The PC12 cell line and the non-neuronal dorsal root ganglion cells secrete a factor into medium that, after adsorption to polylysine-coated surfaces, induces rapid neurite outgrowth by primary sympathetic neurons. The monoclonal antibodies used to purify the neuronal HeS proteoglycan from PC12 cells are capable of depleting this conditioned medium of its neurite-promoting activity. These studies suggest that a HeS proteoglycan synthesized and secreted by neurons and certain accessory cells plays a role in regulating neurite outgrowth.

Proteoglycans have been found in extracellular matrices (Hassell et al., 1980), on the cell surface (Oldberg et al., 1979), and inside of the cell (Pacifici et al., 1983), often associated with particular organelles. Specific proteoglycans have been found in cell adhesion plaques and thereby have been implicated in cell adhesion and motility (Lark and Culp, 1983). Others appear to play important roles

Received August 6, 1984; Revised December 17, 1984;

Accepted December 19, 1984.

${ }^{1}$ This work was supported by grants from the National Institutes of Health (NS 19090), the National Science Foundation (BNS 8100342), the Muscular Dystrophy Association, and the March of Dimes Birth Defects Foundation to L. F. Reichardt. W. D. M. and A. D. I were supported by United States Public Health Service Training Grants GM-07618 and CA-09270, respectively, and R. J. G. was supported by a fellowship from the Helen Hay Whitney Foundation.

${ }^{2}$ To whom correspondence should be sent, at his current address: Department of Neurobiology. Harvard Medical School, 25 Shattuck Street, Boston, MA 02115

${ }^{3}$ Current address: Department of Biology, Princeton University, Princeton, NJ 08544 in organizing basement membranes (Schubert et al., 1983) and regulating the permeability of these membranes to small molecules (Van Harreveld et al., 1971). Proteoglycans have been found in transmitter-containing vesicles and have been postulated to play an important role in transmitter storage (Bennett and Leblond, 1977; Cook, 1977) or in alignment of synaptic structures, by dint of their deposition in the synaptic cleft (Buckley et al., 1983).

Many different cells secrete factors into medium that, when attached to the substrate, induce neurite outgrowth (reviewed by Berg, 1984). One such factor, secreted by corneal endothelial cells, has been partially purified and shown to contain a HeS proteoglycan associated with the biological activity (Lander et al., 1982, 1983). In this report, we describe the biochemical properties of a purified neuronal HeS proteoglycan which is associated with a similar neurite outgrowth activity.

\section{Materials and Methods}

Materials. Chondroitinase $A B C$, chondroitinase $A C$, hyaluronidase, hyaluronic acid (grade IV), trypsin (type III), soybean trypsin inhibitor, and neuraminidase (type IX) were obtained from Sigma Chemical Co.; Pronase was from Calbiochem-Behring Corp.; $\mathrm{CsCl}$ was from Schwartz-Mann; and bovine lung heparan sulfate was from Upjohn Laboratories. Antiserum to NGF was the generous gift of Dr. Eric M. Shooter; crude heparinase was the generous gift of Dr. Alfred Linker.

PC12 cells. The rat pheochromocytoma cell line, PC12 (Greene and Tischler, 1976) was obtained from Dr. D. Schubert (Salk Institute). For preparation of conditioned medium (CM), cells were cultured in Dulbecco's modified Eagle's medium (DMEM) with 5\% fetal calf serum and $10 \%$ horse serum. CM was harvested from cultures that were at least 2 days old with final densities of $10^{6}$ cells $/ \mathrm{ml}$. Serum-free $\mathrm{CM}\left(\mathrm{CM}_{\mathrm{SF}}\right)$ was prepared by incubating confluent monolayers for 2 days in DMEM alone or in DMEM supplemented with transferrin $(50 \mu \mathrm{g} / \mathrm{ml})$, insulin $(5 \mu \mathrm{g} / \mathrm{ml}), \mathrm{SeO}_{2}(4 \mathrm{ng} / \mathrm{ml})$ (Block and Bothwell, 1983), glutamine (2 mM), penicillin (100 U/ml), and streptomycin $(100 \mu \mathrm{g} / \mathrm{ml})$. Both $\mathrm{CM}$ and $\mathrm{CM}_{\mathrm{SF}}$ were centrifuged and filtered through a $0.45-\mu \mathrm{m}$ filter before storage at $4^{\circ} \mathrm{C}$

PC12 membranes were prepared from $5 \times 10^{7}$ cells and rinsed twice with DMEM and once with phosphate-buffered saline (PBS) containing $0.5 \mathrm{~mm}$ phenyimethylsulfonyl fluoride (PMSF). Cells were scraped from the dishes with a rubber policeman in $30 \mathrm{ml}$ of cold PBS/PMSF, homogenized in a glass-Teflon homogenizer and centrifuged at $20,000 \times g$ for $20 \mathrm{~min}$. Then followed four sequential cycles of homogenization and centrifugation at $4^{\circ} \mathrm{C}$ in $\mathrm{H}_{2} \mathrm{O} / \mathrm{PMSF}, 1 \mathrm{M} \mathrm{NaCl} / \mathrm{PMSF}$, PBS/PMSF, and PBS. THe final pellet was resuspended in $1 \mathrm{ml}$ of $\mathrm{PBS}$ and stored at $-80^{\circ} \mathrm{C}$.

Radiolabeling of PC12 cells was carried out by growth in DMEM with no inorganic sulfate, no penicillin or streptomycin sulfate, and only $10 \%$ of normal amino acid concentration, supplemented with $20 \mu \mathrm{Ci} / \mathrm{ml}$ of $\left[{ }^{35} \mathrm{~S}\right]$ sulfate (Amersham/Searle Corp.) and $50 \mu \mathrm{Ci} / \mathrm{ml}{ }^{3} \mathrm{H}$-amino acid mixture (Amersham). Cells were plated at $5 \times 10^{5} / \mathrm{ml}$, grown for 4 days, and then harvested by low-speed centrifugation. $\mathrm{CM}$ was millipore-filtered, adjusted to $1 \%$ calf serum, and stored at $-20^{\circ} \mathrm{C}$.

Immunopurification of the proteoglycan. Isolation of hybridoma-secreting cell lines and preparation of antibodies was carried out as described in Matthew et al. (1981). Immunoaffinity columns were prepared by linking cach of five monoclonal antibodies, purified from ascites fluid, and normal mouse serum to Sepharose $4 B$ (Hudson and Hay, 1976). To purify the antigen, $4 \mathrm{ml}$ of $\mathrm{PC} 12 \mathrm{CM}$, labeled with $\left[{ }^{35} \mathrm{~S}\right]$ sulfate and ${ }^{3} \mathrm{H}$-amino acids, were incubated 
sequentially with $2 \mathrm{ml}$ of each of the Sepharose-antibodies (aPG3, aPG22, aPG42, and normal mouse serum) for $1 \mathrm{hr}$ at $25^{\circ} \mathrm{C}$ with gentle rocking, followed by washing with $100 \mathrm{ml}$ of PBS, $5 \%$ calf serum, and $10 \mathrm{ml}$ of $0.9 \%$ $\mathrm{NaCl}$. In other words, the immunopurified antigen from the aPG3 column was next purified on a column of aPG22 followed by aPG42. The antigen was eluted from the first two antibodies with $0.1 \mathrm{M}$ Na-glycine, $\mathrm{pH} 3.0$. The third immunoaffinity column was eluted with $4 \mathrm{M} \mathrm{GuCl} / 50 \mathrm{~mm}$ Tris, $\mathrm{pH} 7.0$. The nonadhering fraction was collected from the final column of normal mouse. serum.

Density and molecular weight determinations. Samples of radiolabeled PC12 medium were propared for ultracentrifugation by layering $1 \mathrm{ml}$ aliquots onto Bio-Gel P-2 columns (exclusion limit, $M_{\mathrm{r}} 1800$ ) equilibrated with $4 \mathrm{M}$ $\mathrm{GuCl} / 20 \mathrm{~mm}$ Tris, $\mathrm{pH} 7.0$, collecting void volumes, adjusting the total volume to 4.89 rnll with $4 \mathrm{M} \mathrm{GuCl}$, and dissolving $2.87 \mathrm{~g}$ of $\mathrm{CsCl}$ in it. Samples of purified proteoglycan were treated similarly, with the omission of the Bio-Gel P-2 column. Samples were centrifuged to equilibrium in a Beckman SW 50.1 rotor at $40,000 \mathrm{rpm}$ for $70 \mathrm{hr}$. 280- $\mu \mathrm{l}$ fractions were collected, of which $50 \mu \mathrm{l}$ were weighed and then counted in Aquasol.

For gel filtration, $50-\mu$ aliquots of radiolabeled $\mathrm{PC} 12 \mathrm{CM}$ or immunopurified proteoglycan, adjusted to $0.9 \% \mathrm{NaCl}$ or $4 \mathrm{M} \mathrm{GuCl}$, were layered onto Sepharose $\mathrm{CL}-4 \mathrm{~B}$ columns equilibrated with $0.9 \% \mathrm{NaCl}$ or $4 \mathrm{M} \mathrm{GuCl}$ and 50 $\mathrm{mm}$ Tris, $\mathrm{pH} 7.0$ at $4^{\circ} \mathrm{C}$. One-ml fractions were collected, and an aliquot from each fraction was counted in Aquasol. For those fractions containing $4 \mathrm{M}$ $\mathrm{GuCl}$, a $50-\mu$ l sample was layered onto Bio-Gel P-2 columns equilibrated with PBS. The void material was collected and incubated in multiwells or polylysine-coated multiwells for radioimmunoassays. Each of the five antibodies was used to monitor the elution of antigen and gave identical results. Columns were calibrated with $\lg \mathrm{G}\left(M_{\mathrm{r}} 150,000\right)$, ferritin $\left(M_{\mathrm{r}} 440,000\right)$, and $\lg \mathrm{M}\left(M_{\mathrm{r}}\right.$ $1,000,000)$.

Gel filtration of the proteoglycan core protein after $\beta$-elimination was carried out on a $100-\mu \mathrm{l}$ sample of immunopurified proteoglycan by layering it onto a Bio-Gel P-2 column equilibrated with $0.2 \mathrm{M}$ sodium sulfite, $\mathrm{pH} 11.5$ at $25^{\circ} \mathrm{C}$, and incubating the void material at $25^{\circ} \mathrm{C}$ for $24 \mathrm{hr}$ (Simpson et al., 1972). After adjustment to $4 \mathrm{M} \mathrm{GuCl}$, the sample was concentrated by dialysis against solid polyethylene glycol and chromatographed on a Bio-Gel P-150 column equilibrated with $4 \mathrm{M} \mathrm{GuCl} / 50 \mathrm{~mm}$ Tris, $\mathrm{pH} 7.0$. The column was calibrated with chymotrypsinogen $A$, ovalbumin, and bovine albumin.

Carbohydrate chains of the proteoglycan were prepared from a $100-\mu 1$ sample of immunopurifed proteoglycan layered onto a Bio-Gel P-2 column equilibrated with PBS, collected in the void volume, and digested with $1 \mathrm{mg} /$ $\mathrm{ml}$ Pronase for $4 \mathrm{hr}$ at $25^{\circ} \mathrm{C}$. The sample was concentrated to $50 \mu \mathrm{l}$ by dialysis against solid polyethylene glycol at $25^{\circ} \mathrm{C}$ for $2 \mathrm{hr}$, adjusted to $4 \mathrm{M}$ $\mathrm{GuCl}$, and subjected to gel filtration on a Sephadex G-150 column equilibrated with $4 \mathrm{M} \mathrm{GuCl} / 50 \mathrm{~mm}$ Tris, $\mathrm{pH} 7.0$. The eluted fractions were counted in Aquasol. The column was calibrated with samples of dextrans and dextran sulfates of molecular weights $5,000,8,000,10,000,15,000$, and 50,000.

\section{TABLE ।}

\section{Competition between different antibodies}

Five $\mathrm{APG}$ antibodies were tested for steric hindrance of the binding of one of them, ${ }^{125} \mathrm{-aPG} 3$, to synaptic membranes (SM) and PC12 membranes (PC12M). Initially, a serial dilution of each membrane preparation was assayed to ensure that each antigen would be saturated by the concentration of antibody in culture supernatants. Antibody concentrations in the hybridoma supernatants were 5 to $10 \mu \mathrm{g} / \mathrm{ml}$. Limiting amounts of membrane were adsorbed to microwells; then hybridoma supernatants of the different $\mathrm{aPG}$ culture supernatants were incubated in the microwells overnight at $4^{\circ} \mathrm{C}$. A trace amount (approximately $10 \mu \mathrm{g} / \mathrm{ml}$ ) of ${ }^{125}$-aPG3 antibody was added to each microwell, washed, dried and counted. As controls, two antibodies against different determinants were included: aGA9 recognizing galactose moieties on myelin membranes (Matthew, 1981) and aSV48 recognizing a synaptic vesicle protein (Matthew et al., 1981).

\begin{tabular}{|c|c|c|}
\hline \multirow{2}{*}{ Competing Antibody } & \multicolumn{2}{|c|}{$\begin{array}{l}\text { Percentage of } 125 \text { - } \\
\text { aPG3 Binding }\end{array}$} \\
\hline & $S M$ & $\mathrm{PC} 12 \mathrm{M}$ \\
\hline aPG3 & 0 & 0 \\
\hline aPG15 & 38 & 47 \\
\hline aPG22 & 1 & 1 \\
\hline aPG31 & 88 & 69 \\
\hline aPG42 & 32 & 11 \\
\hline aGA9 & 97 & 100 \\
\hline aSv48 & 98 & 99 \\
\hline
\end{tabular}

TABLE ॥

Distribution of HeS proteoglycan in PC12 cells

To measure internal antigen, $10^{7} \mathrm{PC} 12$ cells were washed and trypsinized with $2 \mathrm{mg} / \mathrm{ml}$ trypsin for $30 \mathrm{~min}$ at $25^{\circ} \mathrm{C}$ and then washed twice by pelleting in DMEM at $1000 \times g$ for $5 \mathrm{~min}$. Cells were retrypsinized for $10 \mathrm{~min}$ at $4^{\circ} \mathrm{C}$ and then washed once in DMEM with $5 \%$ fetal calf serum, once in DMEM with $5 \%$ fetal calf serum and $5 \mathrm{mg} / \mathrm{ml}$ soybean trypsin inhibitor, and three times in DMEM. $80 \%$ of the trypsinized cells were frozen immediately after the washes, thawed and homogenized, and then assayed by radioimmunoassay on polylysine-coated multiwell plates. As controls, the $20 \%$ of the cells kept unfrozen were maintained at $4^{\circ} \mathrm{C}$ and assayed for residual surface antigen. These control cells were incubated in suspension with $\mathrm{aPG}$ antibody and then ${ }^{125}$-second antibody and were washed three times between each step. They bound none of the tested antibodies, verifying the complete removal of all surface antigen.

To measure surface antigen, $50-\mathrm{ml}$ cultures of $\mathrm{PC} 12$ cells were grown to $2 \times 10^{5}$ cells $/ \mathrm{ml}$, collected, centrifuged three times in 10 volumes of medium at $500 \times g$ for $10 \mathrm{~min}$, and resuspended at $10^{5} \mathrm{cells} / \mathrm{ml}$. One-milliliter aliquots were plated into each of the 24 wells in a Falcon tissue culture dish and allowed to adhere for $90 \mathrm{~min}$. All subsequent incubations and washes wcre done with ice-cold PC12 medium. Each well was rinsed three times, and 1 $\mathrm{ml}$ of hybridoma culture fluid was applied for $1 \mathrm{hr}$ on ice. Cultures were rinsed four times, and $1 \mathrm{ml}$ containing $1 \mu \mathrm{Ci}$ of ${ }^{125}$-goat anti-mouse lg serum $(20 \mu \mathrm{Ci} / \mu \mathrm{g})$ was added in PC12 medium. After $1 \mathrm{hr}$ on ice, cultures were washed five times and digested with $100 \mu \mathrm{l}$ of $1 \mathrm{mg} / \mathrm{ml}$ Pronase for $1 \mathrm{hr}$ at $25^{\circ} \mathrm{C}$. After addition of $0.4 \mathrm{ml}$ of $10 \%$ SDS, the contents of each well were removed and counted.

To measure secreted antigen, washed cells were grown for $24 \mathrm{hr}$ in fresh growth medium at $2 \times 10^{5}$ cells $/ \mathrm{ml}$ and removed by centrifugation at $500 \times$ $g$ for $10 \mathrm{~min}$. The $\mathrm{CM}$ was filtered through a Millipore filter $(0.22 \mu \mathrm{m})$ and aliquoted into polylysine-coated multiwell plates for radioimmunoassay. Results are presented for two of the aPG antibodies, but all five gave similar results. Controls consisted of wells incubated with medium minus mouse antibodies (100 cpm) or with indifferent antibodies aGA9 and aSV48 (see legend to Table I). All assays were done in triplicate and did not vary by more than $4 \%$

\begin{tabular}{lrrr}
\hline \multirow{2}{*}{ Antibody } & \multicolumn{3}{c}{${ }^{125} \mathrm{cpm}$} \\
\cline { 2 - 4 } & Internal & Surface & Secreted \\
\hline aPG22 & 3485 & 2036 & 1416 \\
aPG3 & 5216 & 2503 & 2300 \\
aSV48 & 3357 & 125 & 82 \\
aGA9 & 76 & 106 & 62 \\
\hline
\end{tabular}

TABLE III

Effects of enzyme digestion on antibody binding

$\mathrm{CM}_{\mathrm{SF}}$ was prepared from PC12 cells as described in "Materials and Methods" and adjusted to $10 \mathrm{mg} / \mathrm{ml}$ bovine serum albumin. Aliquots were incubated for $12 \mathrm{hr}$ at $25^{\circ} \mathrm{C}$ with each enzyme. The digested samples were adsorbed to polylysine-coated assay wells and tested in a radioimmunoas. say.

\begin{tabular}{lccccc}
\hline & & \multicolumn{4}{c}{ Percentage Remaining } \\
\cline { 3 - 6 } Antibody & Control & Hyaluronidase & $\begin{array}{c}\text { Chondroitinase } \\
\text { ABC }\end{array}$ & $\begin{array}{c}\text { Chondroitinase } \\
\text { AC }\end{array}$ & Heparinase \\
\hline aPG3 & 100 & 92 & 102 & 98 & 9 \\
aPG15 & 100 & 83 & 99 & 96 & 21 \\
aPG22 & 100 & 87 & 95 & 101 & 25 \\
aPG31 & 100 & 97 & 96 & 94 & 12 \\
aPG42 & 100 & 86 & 86 & 105 & 18 \\
\hline
\end{tabular}

Solid-phase radioimmunoassay. Radioimmunoassays were done on soluble antigens and membrane preparations after adsorption to polyvinyl chloride 96-well plates (Klinman, 1972). After thorough washing, antibodies were applied to the wells for $6 \mathrm{hr}$ at $25^{\circ} \mathrm{C}$, rinsed well, and then incubated with 125-labeled second antibody, washed, and counted. For competition experiments, the blocking antibody was incubated together with antigen overnight. For radioimmunoassays on soluble glycosaminoglycan-containing material, plates were first coated wilh $0.1 \mathrm{ml}$ of poly-D-lysine at $1 \mathrm{mg} / \mathrm{mill}$ for 


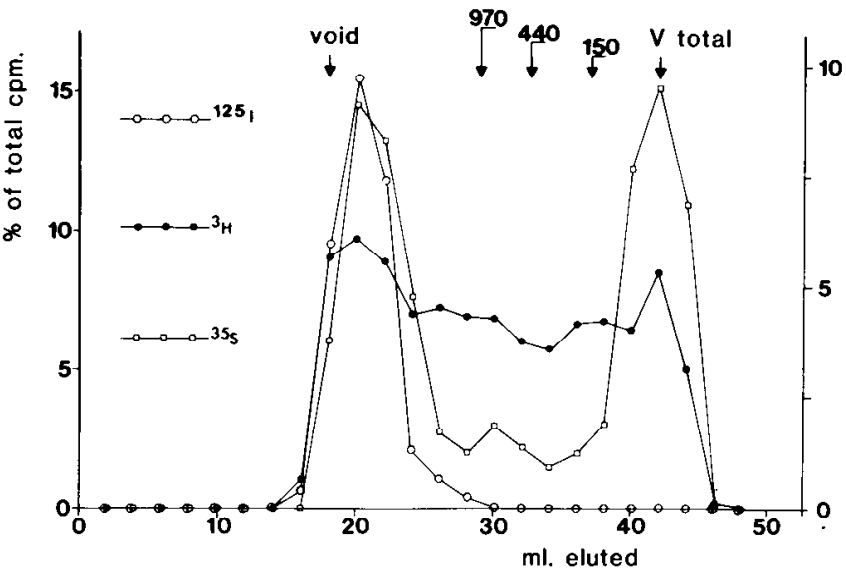

Figure 1. Permeation chromatography of $\mathrm{PC} 12 \mathrm{CM}$ in associative conditions. PC12 CM, metabolically labeled with ${ }^{3} \mathrm{H}$-amino acids and inorganic $\left[{ }^{35} \mathrm{~S}\right.$ /sulfate, was chromatographed on Sepharose CL-4B equilibrated in PBS. The elution profiles of ${ }^{35} \mathrm{~S}(\square),{ }^{3} \mathrm{H}(\bullet)$, and antibody aPG3 binding $(\mathrm{O})$ are shown.

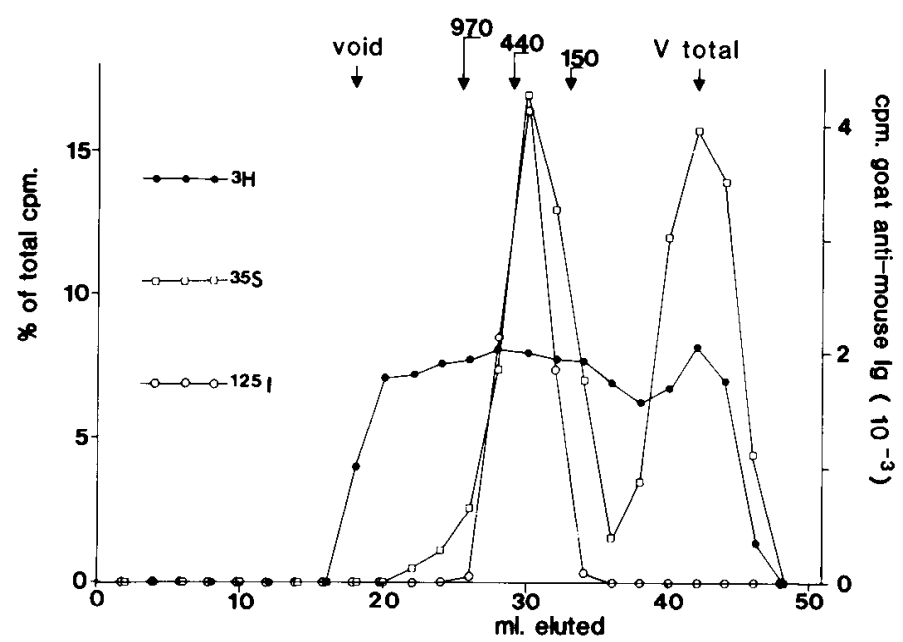

Figure 2. Permeation chromatography of $\mathrm{PC} 12 \mathrm{CM}$ in dissociative conditions. PC $12 \mathrm{CM}$, metabolically labeled with ${ }^{3} \mathrm{H}$-amino acids and inorganic $\left[{ }^{35}\right.$ S]sulfate, was chromatographed on Sepharose CL-4B equilibrated in $4 \mathrm{M}$ GuCl/50 mM Tris-Cl, pH 7.0. The elution profiles of ${ }^{35} \mathrm{~S}(\square),{ }^{3} \mathrm{H}(\boldsymbol{\bullet})$, and antibody aPG3 binding $(\mathrm{O})$ are shown.

$1 \mathrm{hr}$ and then emptied, air dried, and rinsed thoroughly with distilled water. lodination of immunoglobulins was carried out with $1 \mathrm{mCi}$ carrier-free ${ }^{125}$; (Amersham) according to the method of Hunter and Greenwood (1962), to a specific activity of 10 to $30 \mu \mathrm{Ci} / \mu \mathrm{g}$.

As controls in the various antibody experiments, monoclonal antibodies against a synaptic vesicle protein, aSV30 and aSV48 (Matthew et al., 1981), or against galactose moictics on myclin membrancs and desmin intermediate filaments, aGA9 (Matthew, 1981), were used.

Enzymatic treatments. Trypsin was used at $100 \mu \mathrm{g} / \mathrm{ml}$ for $2 \mathrm{hr}$ at $37^{\circ} \mathrm{C}$, after which soybean trypsin intibilur was added to a linal concentration of $500 \mu \mathrm{g} / \mathrm{ml}$. As a control, trypsin inhibitor was used at $100 \mu \mathrm{g} / \mathrm{ml}$ for $2 \mathrm{hr}$ at $37^{\circ} \mathrm{C}$. Neuraminidase was used at $2.5 \mathrm{U} / \mathrm{ml}$ for $5 \mathrm{hr}$ at $37^{\circ} \mathrm{C}$. Chondroitinase $\mathrm{ABC}$ and $\mathrm{AC}$ were used at $2 \mathrm{U} / \mathrm{ml}$ tor 6 hr at $37^{\circ} \mathrm{C}$. Heparinase was used at $30^{\circ} \mathrm{C}$ as indicated.

Primary cell cultures. Sympathetic, sensory, cerebellar, cerebral cortical, and olfactory bulb neurons from neonatal Sprague-Dawley rats were dissociated and cultured as described in Lander et al. (1982); leptomeningeal cells were cultured as described in Raff et al. (1979). Thymocytes and spleen cells were prepared by mechanical shredding of the appropriate adult rat tissues. Fibroblasts and a non-neuronal accessory cell, henceforth referred to as "flat cells," were cultured from dorsal root ganglia prepared according to Fields et al. (1978). Flat cells were obtained by allowing DRG coverslip cultures to grow for 10 to 12 days, by which time they had expanded from 1 to $50 \%$ of the population and formed a very loosely adherent layer on top

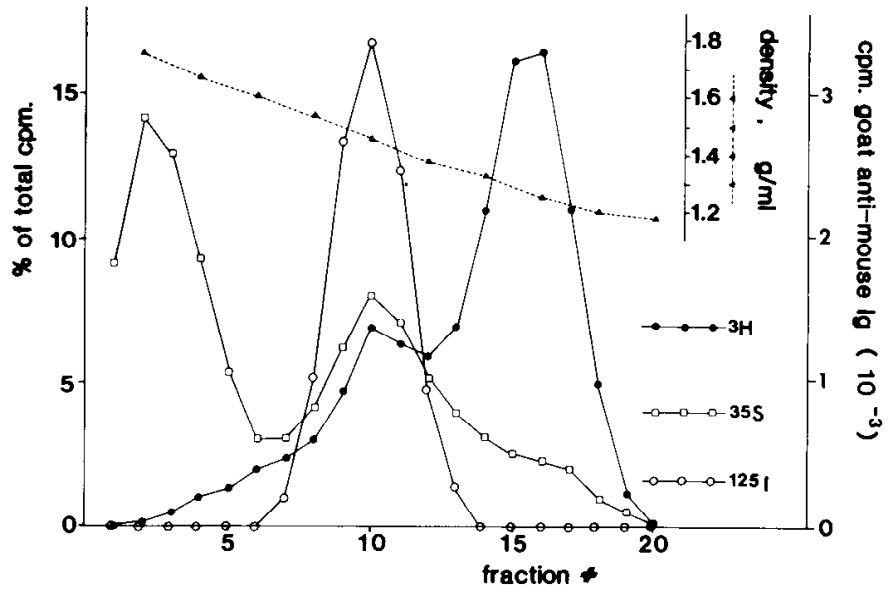

Figure 3. $\mathrm{CsCl}$ density gradient ultracentrifugation of $\mathrm{CM} . \mathrm{PC} 12 \mathrm{CM}$, metabolically labeled with ${ }^{3} \mathrm{H}$ and ${ }^{35} \mathrm{~S}$, was desalted and centrifuged to equilibrium in a $\mathrm{CsCl}$ gradient containing $4 \mathrm{M}$ GuCl. The density (A), ${ }^{3} \mathrm{H}$ distribution (O), ${ }^{35} \mathrm{~S}$ distribution $(\square)$, and antibody aPG22 binding $(O)$ in each fraction are shown.

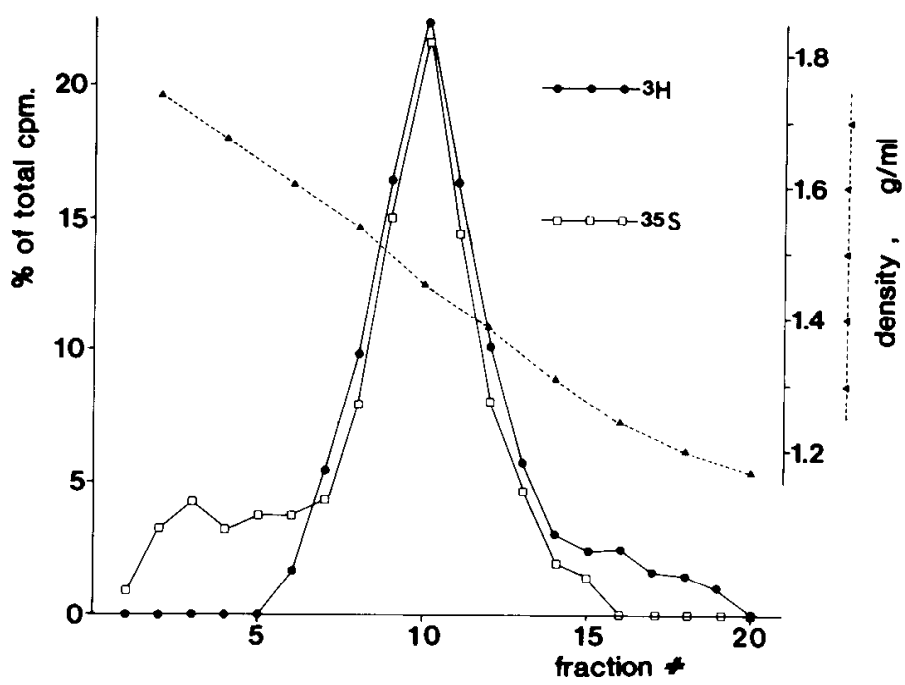

Figure 4. $\mathrm{CsCl}$ density centrifugation of immunopurified antigen. The purified antigen from metabolically labeled $\mathrm{PC} 12 \mathrm{CM}$ was centrifuged as described in Figure 3 . The density $(\mathbf{A}),{ }^{3} \mathrm{H}$ distribution (-), and ${ }^{35} \mathrm{~S}$ distribution (ㅁ) in each fraction are shown.

of all other cell types. An enriched culture was then produced by gently washing the loosely adherent flat cells from the coverslips and plating them in DMEM with $10 \%$ calf serum. An immortal cell line was derived from the enriched culture by maintaining cells in this way for 3 months. CM from flat cells was prepared in the same way as for PC12 cells (see above).

Neurite outgrowth assays. Assays of neurite extension by neonatal cells from rat superior cervical ganglion, preparation of culture substrata from $\mathrm{CM}$, enzymatic treatments of these substrata, and the evaluation of neurite outgrowth were carried out as described in Lander et al. (1982). All values of neurite outgrowth are the averages of two to four assays, each representing counts of 75 to 100 cells.

Immunofluorescence on dissociated cells. Cells were plated on collagen. coated glass coverslips. Primary cells were grown for at least 4 days before staining. Coverslips were removed from the culture dish, rinsed in $5 \%$ calt serum, incubated with undiluted hybridoma culture supernatant for $40 \mathrm{~min}$ at $25^{\circ} \mathrm{C}$, rinsed, incubated with a 40 -fold dilution of fluorescein-coupled goatanti-mouse lg serum for 40 min at $25^{\circ} \mathrm{C}$, mounted in elvanol, and viewed with a Zeiss IM fluorescence microscope. Rabbit sera were generally used at a 100 -fold dilution.

Celi types were identified in thesc cultures by means of cell-type specific antisera in double-label experiments with monoclonal antibodies. Tetanus toxin (a gift of Lederle Laboratories) identified neurons (Fields et al., 1978). In peripheral nervous systern cultures, anti-RAN-1 (a gift of Dr. K. Fields) 


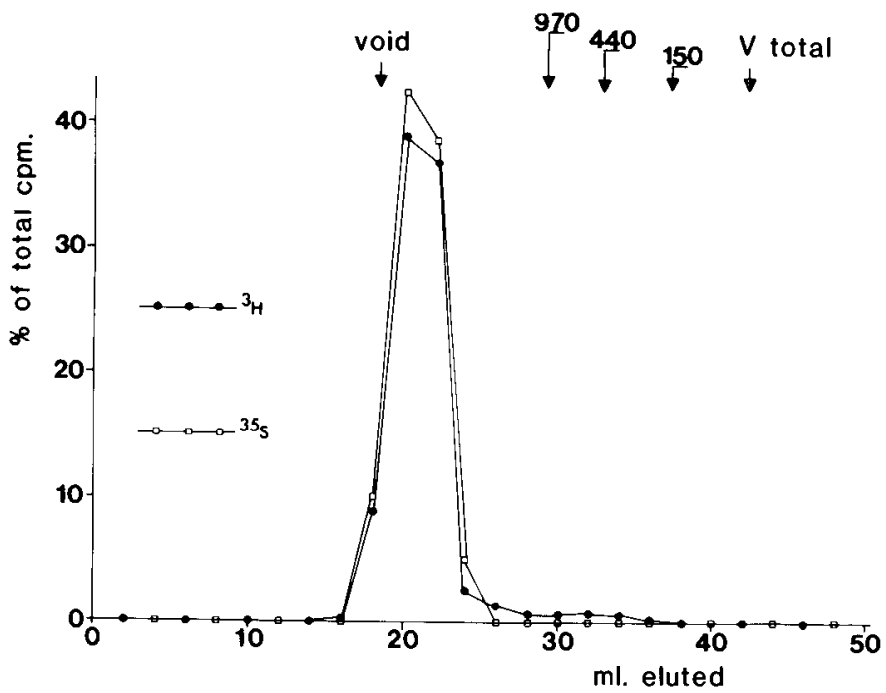

Figure 5. Gel chromatography of immunopurified antigen under associative conditions. The metabolically labeled, purified antigen was chromatographed on Sepharose CL-4B in PBS. The elution profiles of ${ }^{3} \mathrm{H}$-protein (-) and ${ }^{35} \mathrm{~S}$-carbohydrate $(\square)$ are shown.

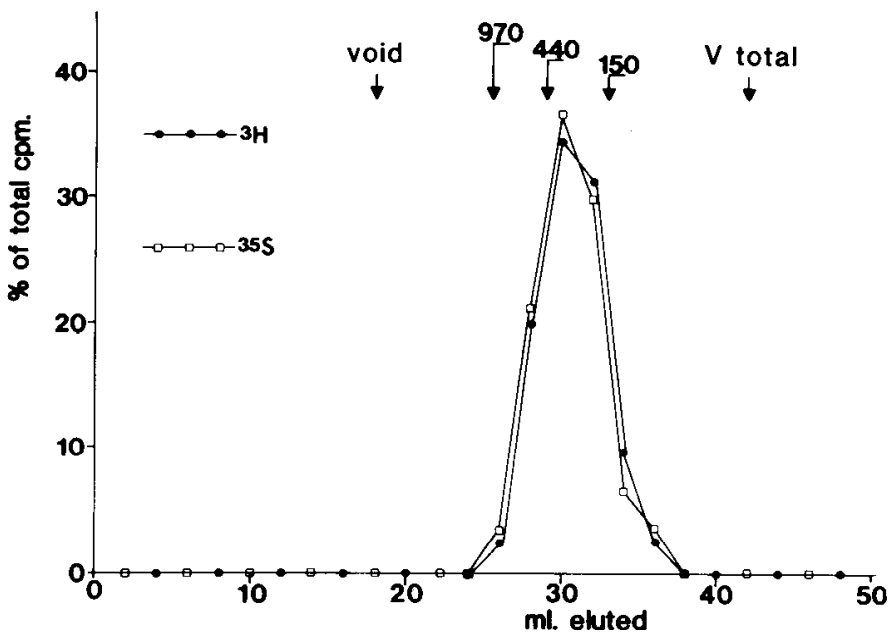

Figure 6. Gel chromatography of immunopurified antigen under dissociative conditions. The metabolically labeled, purified antigen was chromatographed on Sepharose CL-4B in $4 \mathrm{M} \mathrm{GuCl} / 50 \mathrm{~mm}$ Tris, $\mathrm{pH} 7,0$. The elution profiles of ${ }^{3} \mathrm{H}$-protein (-) and ${ }^{35} \mathrm{~S}$-carbohydrate $(\square)$ are shown.

identified Schwann cells. In central nervous system cultures, antigalactocerebroside (a gift of $D$. Shelton) identified oligodendrocytes and antiglial fibrillary acidic protein (a gift of Dr. L. Eng) identified astrocytes (Raff et al., 1979) Fibroblasts fail to bind any of the toxins or sera cited above, and they also have a distinctive appearance. Anti-Thy-1.1 (a gift of Dr. J. Goodman) and antifibroncctin (a gift of Dr. K. Ficlds) bind most of thesc cells (Raff et al., 1979).

Immunoprecipitations of CM neurite-promoting factor from flat cells and $P C 12$ cells. For irmmunoprecipitation of flat cell $C M$, aPG antibodies 15,22 , 31 , and 42 were immobilized by attachment to Sepharose 4B (see above) and, in a separate experiment, by adsorption to formaldehyde-fixed Staph A bacteria. For each antibody, $1 \mathrm{ml}$ of $\mathrm{CM}$ was incubated overnight, gently rocking, with a quantity of packed beads $(1 \mathrm{ml})$ or fixed bacteria $(0.3 \mathrm{ml})$ estimated to carry approximately 1 to $2 \mathrm{mg}$ of bound antibody. After centrifugation and millipore filtering, the $\mathrm{CM}$ supernatant was diluted to a concentration at which unadsorbed $\mathrm{CM}$ gave an approximately half-maximal response (25\% of the cells extending neurites), and it was then applied to the polylysine-coated substrate for the outgrowth assay. Controls consisted of $\mathrm{CM}$ adsorptions with Sepharose $4 \mathrm{~B}$ and Staph A, neither of which had any bound antibody.

In the case of PC12 CM, immunoprecipitations were done with $\mathrm{PPG} 31$ and with an indifferent antibody aSV30, a monoclonal antibody specific for a synaptic vesicle antigen (Matthew et al., 1981). For each antibody, $1 \mathrm{ml}$ of

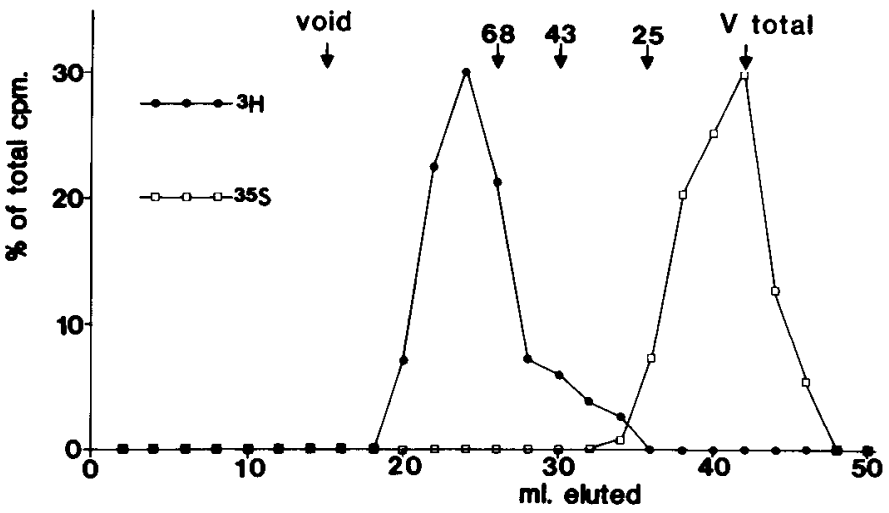

Figure 7. Estimation of core protein molecular weight by chromatography. The metabolically labeled and purified proteoglycan was incubated with 0.2 $M$ sodium sulfite, $\mathrm{pH} 11.5$, for $24 \mathrm{hr}$ at $25^{\circ} \mathrm{C}$; the solution was adjusted to 4 $\mathrm{M} \mathrm{GuCl}$ and chromatographed on Bio-Gel P-150 in $4 \mathrm{M} \mathrm{GuCl} / 50 \mathrm{~mm}$ Tris, $\mathrm{pH}$ 7.0. The elution profiles of ${ }^{3} \mathrm{H}$-protein $\left(-\right.$ ) and ${ }^{35} \mathrm{~S}$-carbohydrate $(\square)$ are shown.

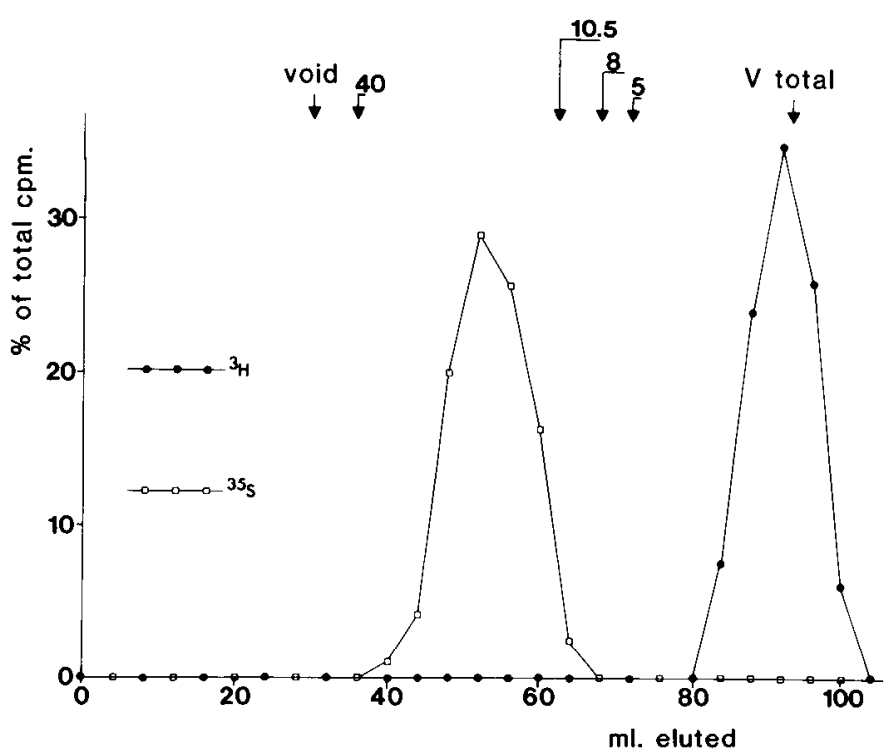

Figure 8. Estimation of GAG molecular weight by chromatography. Metabolically labeled and purified proteoglycan was digested with $1 \mathrm{mg} / \mathrm{ml}$ Pronase and chromatographed on Sephadex G-75 in $4 \mathrm{M} \mathrm{GuCl} / 50 \mathrm{~mm}$ Tris, $\mathrm{pH}$ 7.0. The elution profiles of ${ }^{35} \mathrm{~S}$-carbohydrate $(\square)$ and ${ }^{3} \mathrm{H}$-protein $(\bullet)$ are shown.

$\mathrm{CM}$ was incubated overnight at $4^{\circ} \mathrm{C}$ with a volume of ascites fluid containing $1 \mathrm{mg}$ of antibody. Excess staph A was added to the mixtures, incubated for $1 \mathrm{hr}$, and then removed by centrifugation. The supernatant was milliporefiltered and then assayed as described above.

\section{Results}

Monoclonal antibodies to a neuronal HeS proteoglycan. Five different monoclonal antibodies, made against synaptic junctional protein from rat brain, bind a set of closely neighboring determinants found in synaptic membranes. A competition assay demonstrates this, showing that when one of the antibodies, aPG3, is radioactively labeled, its binding to these membranes is partially inhibited by each of the other four (Table I).

The neuron-like cell line PC12 (Greene and Tischler, 1976) bears an antigenically indistinguishable complex in ils membranes (Table I). Furthermore, these cells secrete the same antigens into the medium, as well as harboring them internally (Table I; cf. Greif and Reichardt, 1982).

Given that all five antibodies recognized the same (presumably major) component and that glycosaminoglycans and proteoglycans 
TABLE IV

Size and antibody binding of purified antigen after digestion

${ }^{35}$ S-labeled proteoglycan was immunopurified from PC12 $\mathrm{CM}_{\mathrm{SF}}$ as described in "Materials and Methods," adjusted to $10 \mathrm{mg} / \mathrm{ml}$ bovine serum albumin, then aliquoted and digested with $1 \mathrm{mg} / \mathrm{ml}$ of each enzyme for $4 \mathrm{hr}$ at $25^{\circ} \mathrm{C}$. Nitrous acid degradation has been described in Lander et al. (1982). Bio-Gel P-6 columns were used to determine the approximate size of ${ }^{35} \mathrm{~S}$ labeled material. Void materials have molecular weights greater than 5,000 , and $V_{\text {Total }}$ materials have molecular weights less than 1,500. The immunoprecipitability of the treated material was assayed in multiwell plates coated with ascites aPG3. Each well received $2000 \mathrm{cpm}$ of ${ }^{35} \mathrm{~S}$ and was incubated for 4 $\mathrm{hr}$ at $25^{\circ} \mathrm{C}$. The nitrous acid treated antigen was not tested in this assay. Values cited are the average of triplicate wells which did not differ by more than $5 \%$.

\begin{tabular}{lrrr}
\hline & \multicolumn{2}{c}{$\begin{array}{c}\text { Percentage of } \\
\mathrm{cpm}\end{array}$} & $\begin{array}{c}\text { Percentage } \\
\text { immunoprecipitable }\end{array}$ \\
\cline { 2 - 3 } & Void & $V_{\text {Total }}$ & \\
\hline Control & 100 & 0 & 90 \\
Hyaluronidase & 90 & 6 & 72 \\
Heparinase & 7 & 91 & 6 \\
Chondroitinase AC & 97 & 1 & 85 \\
Chondroitinase ABC & 90 & 7 & 79 \\
Nitrous acid & 29 & 65 & \\
\hline
\end{tabular}

TABLE $V$

Binding of aPG antihodies to the HeS proteoglycan, lts component core protein, and GAG fragments

The immunopurified HeS proteoglycan antigen, core protein, and GAG chains were assayed in the standard radioimmunoassay (see "Materials and Methods"). Core protein was adsorbed to untreated assay wells, whereas GAG chains were adsorbed to polylysine-coated wells. Assays were done in triplicate and did not vary by more than $3 \%$. Controls included no mouse antibody (100 cpm) and aGA9 and aSV48 (see legend to Table l). Values have had background (approximately $100 \mathrm{cpm}$ ) subtracted.

\begin{tabular}{lccr}
\hline \multirow{2}{*}{ Antibody } & \multicolumn{3}{c}{$\mathrm{cpm}^{125}$-Second Antibody } \\
\cline { 2 - 4 } & $\begin{array}{c}\text { Immunopurified } \\
\text { Antigen }\end{array}$ & $\begin{array}{c}\text { Core } \\
\text { Protein }\end{array}$ & $\begin{array}{c}\text { GAG } \\
\text { Chain }\end{array}$ \\
\hline aPG3 & 9764 & 7 & 1998 \\
aPG15 & 4264 & 370 & 76 \\
aPG22 & 8165 & 650 & 90 \\
aPG31 & 6090 & 15 & 1689 \\
aPG42 & 7442 & 287 & 56 \\
aGA9 & 9 & 0 & 0 \\
aSV48 & 35 & 1 & 7 \\
\hline
\end{tabular}

are abundant in brain (Margolis, 1967; Margolis et al., 1972), it seemed reasonable to test for linkage between the antigens and glycosaminoglycan. Enzyme treatments of CM containing the antigens from PC12 cells demonstrate that all five determinants are closely associated with a heparan sufate-containing molecule (Table III), inasmuch as heparinase destroys their binding to polylysine.

Further evidence for the proteoglycan nature of the molecule comes from permeation chromatography under associating and dissociating conditions. Proteins in CM from PC12 cells were metabolically labeled with ${ }^{3} \mathrm{H}$-amino acids, while sulfated carbohydrates, including glycosaminoglycans, were labeled with ${ }^{35}$ S]sulfate. Permeation chromatography on Sepharose 4B, followed by an antibody binding assay to the different fractions, shows the antigens eluting in a unimodal peak centered under the major macromolecular peak of sulfate label and one of the main peaks of amino acid incorporation (Fig. 1), corresponding to a molecular weight of approximately $10,000,000$ for a compact protein. Fractionation of similarly radiolabeled $\mathrm{CM}$ in the presence of $4 \mathrm{M}$ guanidine chloride ( $\mathrm{GuCl}$ ), conditions that dissociate proteoglycan complexes, produces a coincident shift in the peaks of sulfate labeling and of antibody binding (Fig. 2),
TABLE VI

Solubilization of antigen from synaptic membranes

Column headings refer to solubilization treatments; row titles refer to the subcellular fraction assayed. A $100-\mu$ laliquot of synaptic membranes in PBS (protein $-100 \mu \mathrm{g} / \mathrm{ml}$ ) was adjusted to $0.1 \%$ Triton $X 100$ (TX 100) and incubated for $20 \mathrm{~min}$ at $25^{\circ} \mathrm{C}$. An identical sample was maintained in PBS. Both samples were centrifuged at $100,000 \times g$ for $1 \mathrm{hr}$ in an airfuge (Beckman). The pellets were washed two additional times in PBS. Supernatants from the three centrifugations were pooled for assay. The final pellets were resuspended in PBS. The total number of antigen units in supernatants and pellets was determined for each sample by radioimmunoassay (see "Materials and Methods"). The samples containing Triton were diluted 50-fold in PBS containing $5 \%$ calf serum in order to permit binding to the plate.

Trypsin treatment consisted of incubating 4-ml synaptic membranes in PBS (protein $=10 \mu \mathrm{g} / \mathrm{ml}$ ) with $0.025 \%$ trypsin $/ 5 \mathrm{~mm}$ EDTA/5 mM EGTA for $20 \mathrm{~min}$ at $37^{\circ} \mathrm{C}$. The reaction was terminated with $0.03 \%$ soybean trypsin inhibitor, and the membranes were pelleted at $10,000 \times g$ for $15 \mathrm{~min}$. The supernatant was recovered, and $100-\mu \mathrm{l}$ aliquots were adsorbed to multiwell plates for $2 \mathrm{hr}$ at $25^{\circ} \mathrm{C}$ and $10 \mathrm{hr}$ at $4^{\circ} \mathrm{C}$. The membrane pellet was washed three times and separated into 40 microfuge tubes. Forty equivalent tubes of untrypsinized synaptic membrane were aliquoted in parallel. The amount of antigen was quantified by binding aPG 22 or aPG31 and ${ }^{125}$-goat antimouse $\mathrm{lg}$ serum in solution. The membranes were washed three times between each incubation by pelleting at $10,000 \times g$ for $10 \mathrm{~min}$. In both assays, the monoclonal antibody and goat anti-mouse lg serum were used at saturating concentrations. Controls included normal mouse serum or the absence of mouse antibody. Each assay was done in triplicate, and values did not vary by more than $4 \%$. Values are expressed as a percentage of total binding in the control.

\begin{tabular}{|c|c|c|c|c|c|c|}
\hline \multirow{2}{*}{ aPG Antibody } & \multicolumn{2}{|c|}{ PBS } & \multicolumn{2}{|c|}{$T X-100$} & \multicolumn{2}{|c|}{ Trypsin } \\
\hline & 22 & 31 & 22 & 31 & 22 & 31 \\
\hline Membrane & 98 & 99 & 97 & 98 & 67 & 76 \\
\hline Soluble & 2 & 1 & 3 & 2 & 56 & 76 \\
\hline Total & 100 & 100 & 100 & 100 & 123 & 152 \\
\hline
\end{tabular}

down to a position corresponding to a molecular weight of approximately 350,000.

Since most proteoglycans have buoyant densities intermediate between protein and carbohydrate, they can be separated from proteins and glycoproteins in density gradients. $\mathrm{CsCl}$ density gradient centrifugation of radiolabeled $\mathrm{CM}$ from $\mathrm{PC} 12$ cells in the presence of $4 \mathrm{M} \mathrm{GuCl}$ gives results consistent with a proteoglycan identity for the antigens (Fig. 3 ). The major peak of ${ }^{3} \mathrm{H}$-labeled protein equilibrates at $1.30 \mathrm{~g} / \mathrm{ml}$, while a smaller protein peak coincient with a peak of ${ }^{35} \mathrm{~S}$-labeled carbohydrate equilibrates at $1.45 \mathrm{~g} / \mathrm{ml}$. The remainder of radioactive sulfate is concentrated at the bottom of the gradient $(1.60 \mathrm{~g} / \mathrm{ml})$. Antibody binding activity equilibrates as a single molecular species at $1.45 \mathrm{~g} / \mathrm{ml}$, coinciding exactly with the superimposed peaks of ${ }^{3} \mathrm{H}$ and ${ }^{35} \mathrm{~S}$.

Purification and characterization of the antigen. A conclusive demonstration that these antigens are part of a unique proteoglycan requires that a purified molecule retain all of the properties found associated in CM. To this end, radiolabeled CM from $\mathrm{PC} 12$ cells was subjected to sequential immunopurification with monoclonal antibodies aPG3, aPG22, and aPG42 as described in "Materials and Methods," and the purified antigen was compared to whole CM.

The purified antigen equilibrates in a dissociating $\mathrm{CsCl}$ gradient at a density identical to that found with $\mathrm{CM}(1.45 \mathrm{~g} / \mathrm{ml})$, with over $90 \%$ of the ${ }^{35} \mathrm{~S}$ - and ${ }^{3} \mathrm{H}$-label forming a monotonic peak (Fig. 4). The residual protein and sulfated carbohydrate may have been specifically associated with the proteoglycan under the nondenaturing conditions of purification, only to be dissociated by GuCl in the gradient.

Permeation chromatography also indicates nearly homogeneous purity of the antigen and once again matches the findings with whole $\mathrm{CM}$. Under associative conditions, the purified proteoglycan elutes as a single peak of molecular weight of approximatcly 

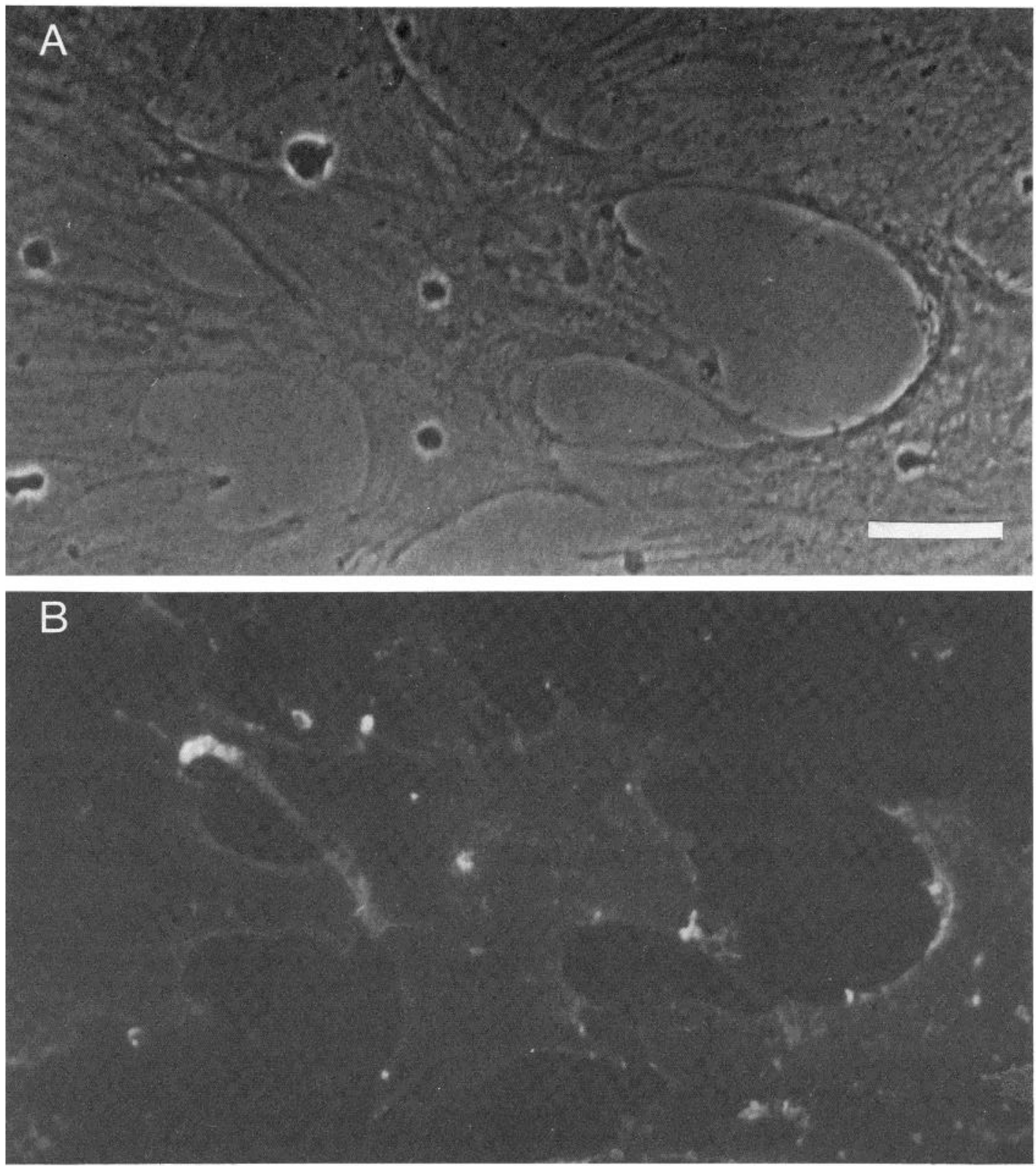

Figure 9. Flat cells derived from DRG cultures. (A) Phase-contrast micrograph. $(B)$ Indirect immunofluorescence with aPG3. Bar $=50 \mu \mathrm{m}$.

$10,000,000$ (Fig. 5), as if associated in a large complex. In $\mathrm{GuCl}$, it elutes as a single peak of apparent molecular weight of 350,000 (Fig. 6). Even though the standards used were proteins, not proteoglycans, this is probably a reasonable estimate of molecular weight, since the standards are extended in $4 \mathrm{M} \mathrm{GuCl}$ (Tanford, 1968). The coincidence of ${ }^{3} \mathrm{H}$ and ${ }^{35} \mathrm{~S}$ in a single peak indicates that the proteoglycan is considerably pure.

Characterization of protein and cabohydrate moieties. Treatment of proteoglycans with mild alkali destroys protein-O-glycosaminoglycan linkages by $\beta$-elimination (Simpson et al., 1972). A sample of purified proteoglycan so treated was chromatographed in dissociative conditions on Bio-Gel P-150, producing a single protein peak with apparent molecular weight of 80,000 (Fig. 7). Since the protein core may still contain $\mathrm{N}$-linked, unsulfated carbohydrate side chains, this may be an overestimate. The ${ }^{35}$ S-GAG molecules migrate very near the end of this chromatography, as expected for molecules of molecular weight 10,000 to 15,000 .

A more accurate size measurement of the GAG side chains was obtained after Pronase digestion of the purified proteoglycan and chromatography on Sephadex G-75 (Fig. 8). Now the ${ }^{35}$ S-label elutes as a single peak of molecular weight 15,000 .

Enzyme treatments verified that the GAG side chains of this proteoglycan are indeed $\mathrm{HeS}$. Digestion of purified proteoglycan with hyaluronidase, chondroitinase $\mathrm{ABC}$, or chondroitinase $\mathrm{AC}$ had no effect on its apparent molecular weight in a Bio-Gel column, while both heparinase and nitrous acid reduced its apparent size (Table IV). Nitrous acid specifically hydrolyzes HeS (Cifonelli, 1968). Coincident with a reduction in molecular weight, heparinase treatment also specifically eliminated binding of aPG3 (Table IV). Taken altogether, these data describe a proteoglycan consisting of approximately $18 \mathrm{HeS}$ side chains linked to a protein core.

The separability of the proteoglycan into protein core and $\mathrm{HeS}$ side chains made possible a determination of which antibodies specifically bound one moiety as opposed to the other. Pronase digestion provided isolated heparan sulfate chains, while mild alkali treatment followed by gel filtration yielded protein cores, and these were assayed for antigenic activity in solid-phase radioimmunoassays. Each antibody binds protein or carbohydrate but not both 

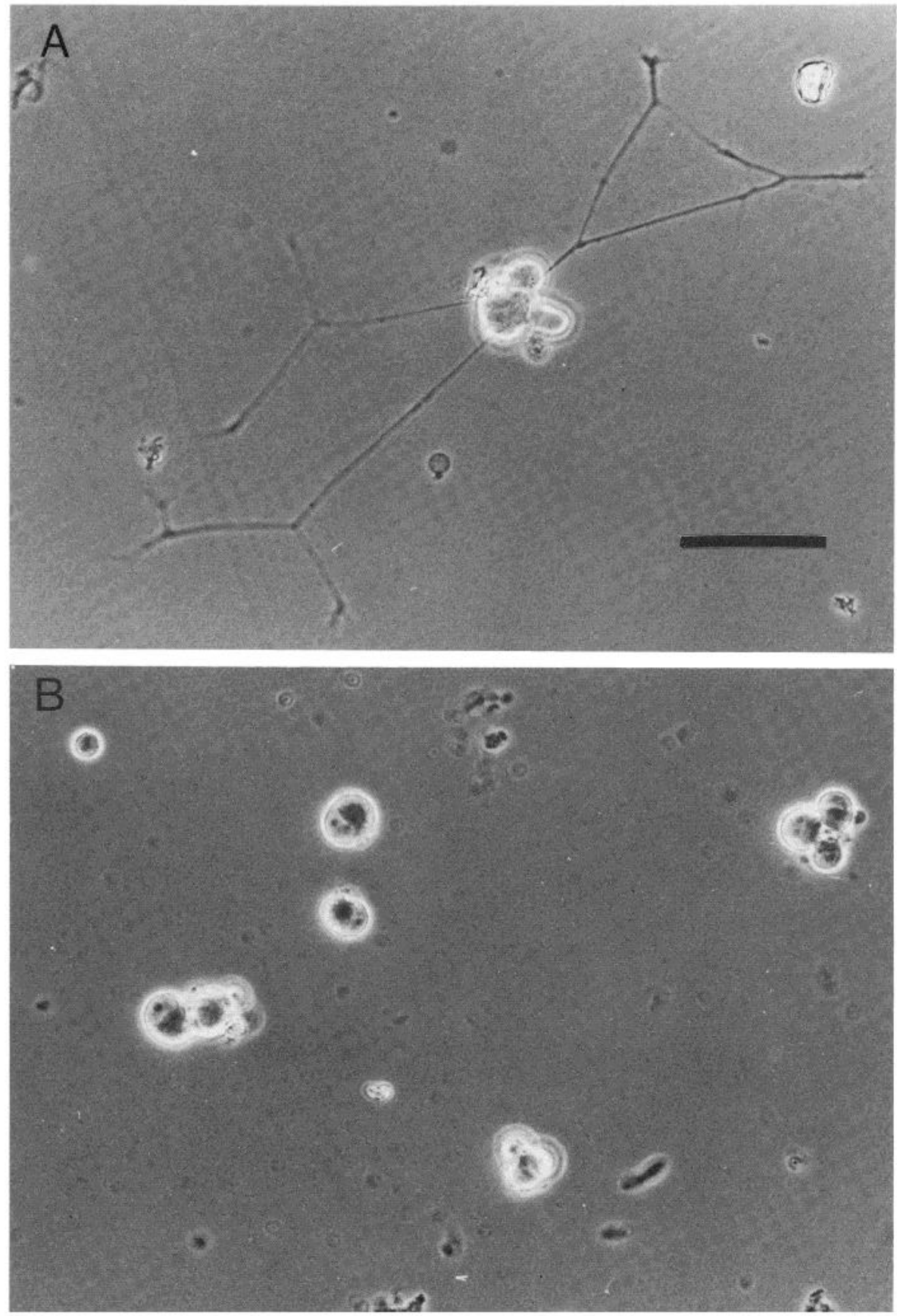

Figure 10. Neurite outgrowth response to flat cell CM. Primary rat superior cervical ganglion neurons were plated onto polylysine substrata which had been incubated with $(A)$ flat cell $\mathrm{CM}$ or $(B)$ fresh medium and photographed $8 \mathrm{hr}$ later. $B a r=$ $50 \mu \mathrm{m}$.
(Table V), with antibodies aPG15, aPG22, and aPG42 specific for the former and aPG3 and aPG31 specific for the latter. None of the antibodies shows signficant binding to purified $\mathrm{HeS}$ from bovine lung (data not shown).

Distribution of the antigen. Having purified a HeS proteoglycan from pheochromocytoma cells with antibodies made against synaptic junctional protein from brain, it was of interest to know where else this molecule resided. As described earlier, it is present in synaptic membranes from rat brain. This form turns out to be insoluble in non-ionic detergents (Table $\mathrm{VI}$ ), requiring sodium dodecyl sulfate for full solubilization. Mild trypsinization of these membranes releases a soluble form of the molecule, as measured by antibody binding to supernatant as opposed to the treated membranes (Table $\mathrm{VI}$ ); it also apparently exposes more antigenic sites. These results suggest that the antigenic determinants are linked to the cell membrane by means of a trypsin-sensitive protein.

The cell types displaying these antigens, as assayed by immu- nofluorescence on dissociated cells, are neurons, thymocytes, PC12 cells, and a previously unidentified non-neuronal accessory cell found in DRG cultures, "flat cells" (Fig. 9; also see "Materials and Methods"). In all cases except thymocytes, the cells stained positively and with a similar pattern for all five aPG antibodies. Subpopulations of thymocytes showed differential staining for the antigens defined by aPG31 or aPG42, representing the only instance encountered so far in which the five determinants do not colocalize to the same molecule. The neurons tested came from cerebellum, cerebral cortex, superior cervical ganglion, and dorsal root ganglion. Oligodendrocytes, leptomeningeal cells, and Schwann cells failed to stain for the antigens, as did astrocytes (except for a subpopulation found in optic nerve). Fibroblasts and spleen cells did not display the antigens either.

Flat cells distinguish themselves by their constellation of surface antigens. While resembling fibroblasts in many respects-morphology in phase-contrast, positive staining for anti-Thy-1.1, failure to 
TABLE VII

Immunoprecipitation of neurite-inducing factor by aPG antibodies

Flat cell CM was incubated with $\mathrm{APG}$ antibodies bound previously to either Sepharose 4B or Staph A and then centrifuged, and the supernatant filtered and assayed as described in "Materials and Methods." In the controls, CM was incubated with either Sepharose or Staph A containing no bound antibody or else was not adsorbed at all.

$\mathrm{PC} 12 \mathrm{CM}_{\mathrm{SF}}$ was incubated with $1 \mathrm{mg}$ ascites and then precipitated with excess Staph A and assayed as described in "Materials and Methods." Controls were done with the an antibody (aSV30) that recognizes a synaptic vesicle protein (Matthew et al., 1981) or with no CM.

Percentage of

Responding Neurons

$\begin{array}{lr}\text { A. "Flat cell" CM } & \\ \text { Antibody } & \\ \text { Sepharose or Staph A alone } & 21.0 \pm 7.3^{a} \\ \text { aPG15 } & 9.3 \pm 1.3 \\ \text { aPG22 } & 5.5 \pm 3.4 \\ \text { aPG31 } & 8.5 \pm 2.6 \\ \text { aPG42 } & 10.0 \pm 6.1 \\ \text { B. PC12 CM } & \\ \text { aSV30 } & 37.6^{\circ} \\ \text { aPG31 } & 5.0 \\ \text { Without CM } & 4.2\end{array}$

${ }^{a}$ Mean \pm SD for four assays.

${ }^{b}$ Average of duplicate assays.

stain with anti-RAN-1, anti-glial fibrillary acidic protein, or tetanus toxin-they differ in their failure to stain with anti-fibronectin. Moreover, the five aPG antibodies stain flat cells in a similar speckled pattern (Fig. 9) while failing to stain fibroblasts at all. Flat cells comprise a very small fraction (approximately $1 \%$ ) of cells in freshly dissociated cultures of DRG, as well as in other tissues tested, supcrior cervical ganglion, cerebral cortex, and rat heart.

Antibodies precipitate neurite promoting activity from PC12 and flat cell CM. Given that the neurite outgrowth activity described by Lander et al. (1982) is associated with a heparan sulfate proteoglycan, that PC12 cells synthesize and secrete a heparan sulfate proteoglycan, and that flat cells appear to make the same molecule, we reasoned that these two cell types were likely to produce a similar activity. $\mathrm{CM}$ and $\mathrm{CM}_{\mathrm{SF}}$ from cultures of either of these cell types, when first attached to a polylysine substrate, will induce vigorous neurite extension of neonatal superior cervical ganglion neurons within $16 \mathrm{hr}$ (Fig. 10). The polylysine substrate serves to attach and presumably concentrate the anionic proteoglycan material (cf. Lander et al., 1982). Under these conditions, neurite growth requires neither NGF nor serum.

Moreover, the activity obtained from PC12 cells is sensitive, in this assay, to the enzymes trypsin and heparinase, but not to hyaluronidase, chondroitinase $A B C$, or chondroitinase $A C$ (flat cell $C M$ was not tested in this experiment). Trypsin and heparinase reduced the neurite outgrowth response to background levels $(5 \%)$, while the other enzyme treatments gave results comparable to controls with no enzyme or with trypsin plus soybean trypsin inhibitor (range, 18 to $28 \%$ ).

With the demonstration that these cells do make the neurite activity and that it behaves as if associaled with a HeS proteoglycan, we reasoned further that the aPG antibodies ought to be capable of removing this activity from $C M$. Immunoprecipitation experiments of flat cell or PC12 CM with aPG antibodies confirmed our expectation (Table VII). With flat cell CM, several antibodies were tried and, not surprisingly, they differed in the efficiency with which they removed the activity. The results indicate association of this unique complex of antigens with neurite-promoting activity and therefore, as defined by the PC12 cells, with the HeS proteoglycan the biochemical identity of which we have established.

Attempts to induce neurite outgrowth with the immunopurified
HeS proteoglycan failed. Two different preparations were tried, one having been eluted in the final step with $4 \mathrm{M} \mathrm{GuCl}$, the other with $0.1 \mathrm{M}$ glycine, $\mathrm{pH} 3$. Under either set of conditions, dissociation of other proteins or denaturation of the proteoglycan would be likely (cf. Lander et al., 1983).

\section{Discussion}

Monoclonal antibodies prepared against synaptic membranes have identified a unique HeS proteoglycan. Molecular weights for each component of this molecule have been estimated by gel filtration. The core protein appears to have a molecular weight of 80,000 , the HeS side chairs have a molecular weight of 15,000, and the whole molecule has a molecular weight of 350,000 . While we have purified only the PC12 molecule, we have identified a protein in brainsynaptic membranes that shares important biochemical and antigenic characteristics (cf. Rapraeger and Bernfield, 1983). Likewise, the flat cell molecule, in addition to sharing antigenic identity, displays an analogous biological property: association with a neuritepromoting activity. These correlations suggest that the aPG antibodies recognize and define a HeS proteoglycan which is common to central and peripheral neurons as well as present on a previously unidentified non-neuronal accessory cell, which we have named flat cells.

Functions for proteoglycans are unknown, though as many have been proffered as there are putative locations for the molecules. Their postulated roles include control of tissue hydration (Polansky et al., 1974), maintenance of structural integrity (Mustafa and Kamat, 1973), control of neuronal migration and differentiation (Margolis et al., 1975), regulation of segregation and storage of other molecules (Farquhar and Palade, 1981), and mediation of adhesion by fibroblasts (Lark and Culp, 1983), myoblasts (Schubert et al., 1983), and synaptic terminals (Buckley et al., 1983).

Experiments with CM from corneal endothelial cells by Lander et al. (1982) first established a link between an activity-promoting neurite outgrowth and HeS proteoglycan. Two hypotheses arose from the work, indistinguishable at the time, regarding the relationship of the proteoglycan to the activity. Either the proteoglycan is the activity, or else it is part of a complex containing the activity. Subsequent work has made it clear that another molecule is necessary for this activity. A monoclonal antibody raised against PC12 cell $C M$ and capable of blocking neurite extension (Matthew and Patterson, 1983) recognizes the $M_{\mathrm{r}} 350,000$ proteoglycan only when it is associated with a nonsulfated molecule the molecular weight of which is approximately 1 million in $4 \mathrm{M} \mathrm{GuCl}$. Moreover, this blocking antibody fails to stain neurons at all, and it does stain peripheral glial cells. Independent evidence comes from further purification of the activity from bovine corneal endothelial cells, demonstrating a separable, nonproteoglycan protein factor capable of eliciting the response (Lander et al., 1983; A. L. Lander, unpublished data).

The association of a neurite-promoting factor with HeS proteoglycan, however, remains a consistent observation, bolstered by the results reported here. Our findings demonstrate that two different cell types synthesize and secrete the same antigenically distinct HeS proteoglycan and that, in both cases, it is part of an apparent complex with neurite-promoting activily. Plausibly, such an association could be a vehicle for ensuring proper deposition of the factor in the extracellular matrix. Given the apparent involvement of proteoglycans in cellular adhesion complexes (e.g., Lark and Culp, 1983; Schubert et al., 1983), and the presence of our HeS proteoglycan on neuronal surface membranes, its propensity for association with neurite outgrowth factor could also indicate an adhesive role for the proteoglycan in binding the neuron to its extracellular substratum.

\section{References}

Bennett, G., and Leblond, C. P. (1977) Biosynthesis of the glycoproteins present in plasma membrane, lysosomes, and secretory materials as visualized by radioautography. Histochem. J. 9: 393-417. 
Berg, D. K. (1948) New neuronal growth factors. Annu. Rev. Neurosci. 7: 149-170.

Block, T., and Bothwell, M. (1983) Use of iron- or selenium-coupled monoclonal antibodies to cell-surface antigens as a positive selection system for cells. Nature 301: 342-344.

Buckley, K. M., Schweitzer, E. S., Miljanich, G. P., Clift-O'Grady, L., Kushner, P. D., Reichardt, L. F., and Kelly, R. B. (1983) A synaptic vesicle antigen is restricted to the junctional region of the presynaptic plasma membrane. Proc. Natl. Acad. Sci. U. S. A. 80: 7342-7346.

Cifonelli, J. A. (1968) Reaction of heparitin sulfate with nitrous acid. Carbohydr. Rcs. 8: 233242.

Cook, G. M. W. (1977) Biosynthesis of plasma membrane proteins. In Synthesis, Assembly, and Turnover of Cell Surface Components, G. Poste and G. L. Nicolson, eds., pp. 85-136, Elsevier/North Holland, Amsterdam.

Edelman, G. M., and Rutishauser, U. (1974) Specific fractionation and manipulation of cells with chemically dervatized fibers and surfaces. Methods Enzymol. 34: 195-228.

Farquhar, M. G., and Palade, G. E. (1981) The Golgi apparatus. J. Cell Biol. 91: 77s-103s

Fields, K. L., Brockes, J. P., Mirsky, R., and Wendon, L. M. B. (1978) Cell surface markers for distinguishing different types of rat dorsal root ganglion cells in culture. Cell 14:43-51.

Greene, L., and Tishler, A. (1976) Establishment of a noradrenergic clonal line of rat adrenal pheochromocytoma cells which responds to nerve growth factor. Proc. Natl. Acad. Sci. U. S. A. 73: 2424-2428.

Greif, K. F., and Reichardt, L. F. (1982) Appearance and distribution of neuronal cell surface and synaptic vesicle antigens in the developing rat superior ganglion. J. Neurosci. 2: 843-852.

Hassell, J. R., Robey, P. G., Barrach, H. J., Wilczek, J., Rennard, S. I., and Martin, G. R. (1980) Isolation of a heparan sulfate containing proteoglycan from basement membrane. Proc. Natl. Acad. Sci. U. S. A. 77: 4494-4498.

Hudson, L., and Hay, F. C. (1976) Practical Immunology, Blackwell Scientific, Oxford.

Hunter, W. M., and Greenwood, F. C. (1962) Preparation of iodine 131 labelled human growth hormone of high specific activity. Nature 194: 495496.

Jones, D. H., and Matus, A. I. (1974) Isolation of synaptic plasma membranes from brain by combined flotation-sedimentation density gradient centrifugation. Biochim. Biophys. Acta 356: 276-287.

Klinman, N. R. (1972) The mechanism of antigenic stimulation of primary and secondary clonal precursor cells. J. Exp. Med. 136: 241-260

Lander, A. D., Fujii, D. K., Gospodarowicz, D. and Reichardt, L. F. (1982) Characterization of a factor that promotes neurite outgrowth: Evidence linking activity to a heparan sulfate proteoglycan. J. Cell Biol. 94: 574585.

Lander, A. D., Tomaselli, K., Calof, A. L., and Reichardt, L. F. (1983) Studies on extracellular matrix components that promote neurite outgrowth. Cold Spring Harbor Symp. Quant. Biol. 48: 611-624.

Lark, M. W., and Culp, L. A. (1983) Moditication of proteoglycans during maturation of fibroblast substratum adhesion sites. Biochemistry 22: 22892296.

Margolis, R. U. (1967) Acid mucopolysaccharides and proteins of bovine whole brain, white matter, and myelin. Biochim. Biophys. Acta 141: $91-$ 102.

Margolis, R. U., Margolis, R. K., and Atherton, D. M. (1972) Carbohydratepeptide linkages in glycoproteins and mucopolysaccharides from brain J. Neurochem. 19: 2317-2321.

Margolis, R. U., Margolis, R. K., Chang, L. B., and Preti, C. (1975) Glycos aminoglycans of brain during development. Biochemistry 14: 85-88.

Matthew, W. D. (1981) Biochemical studies using monoclonal antibodies to neural antigen. Ph.D. Thesis, University of California, San Francisco.

Matthew, W. D., and Patterson, P. (1983) The production of a monoclonal antibody which blocks the action of a neurite outgrowth promoting factor Cold Spring Harbor Symp. Quant. Biol. 48: 625-631.

Matthew, W. D., Tsavaler, L., and Reichardt, L. F. (1981) Identification of a synaptic vesicle-specific membrane protein with a wide distribution in neuronal and neurosecretory tissue. J. Cell Biol. 91: 257-269.

Mustafa, M., and Kamat, D. N. (1973) Mucopolysaccharide histochemistry of Musca domestica. VII. The brain. Acta Histochem. (Jena) 45: 254-269.

Oldberg, A., Kjellan, L., and Hook, M. (1979) Cell surface heparan sulfate. J. Biol. Chem. 254: 8505-8510.

Pacifici, M., Soltesz, R., Thal, G., Shanley, D. J., Boettinger, D., and Holtzer, $\mathrm{H}$. (1983) Immunological characterization of the major chick cartilage proteoglycan and its intracellular localization in cultured chondroblasts. A comparison with type II Procollagen. J. Cell Biol. 97: 1724-1736.

Polansky, J. R., Toole, B. P., and Gross, J. (1974) Brain hyaluronidase Changes in activity during chick development. Science 183: 862-864.

Raff, M. C., Fields, K. L., Hakamori, S., Mirsky, R., Pruss, R. M., and Winter, J. (1979) Cell type specific markers for distinguishing and studying neurons and the major classes of glial cells in culture. Brain Res. 174: 283-308.

Rapraeger, A. C. and Bernfield, M. (1983) Heparan sulfate proteoglycan from mouse mammary epithelial cells. J. Biol. Chem. 258: 3632-3636

Schubert, D., LaCorbriere, M., Klier, F. G., and Birdwell, C. (1983) The structure and function of myoblast adherons. Cold Spring Harbor Symp. Quant. Biol. 48: 539-549.

Simpson, D. L., Hranisaljevic, J., and Davidson, E. A. (1972) Beta-elimination and sulfite addition as a means of localization and identification of substituted seryl and threonyl residues in proteins and proteoglycans. Biochem istry 11: 1849-1856.

Tanford, C. (1968) Protein denaturation. Adv. Protein Chem. 23: 121-282.

Van Harreveld, A., Dafny, N., and Khattab, F. I. (1971) Effects of calcium on the electrical resistance and extracellular space of cerebral cortex. Exp. Neurol. 31: 358-367. 